\title{
Toward a Ripple Effect: Psychologists Collaborate in Social Justice Education at a High School
}

\author{
Grace S. Kim \\ Boston University
}

\author{
Vali D. Kahn \\ John Tawa \\ Karen L. Suyemoto \\ University of Massachusetts Boston
}

\begin{abstract}
Social justice education aims to develop critical thinking about social inequities and social responsibility to increase civic engagement in high school youth. While high schools increasingly recognize the importance of social justice education, teachers are often initially under-prepared to teach this material, particularly about managing challenging emotions, and working with a group-processes as students work with social justice content and process. Psychologists are often asked to be diversity consultants or instructors, creating opportunities to contribute to social justice education. Drawing from implementation science, this paper describes a model of collaboration between university-based psychologists and high-school educators in providing a social justice course to high school students. Our education model enabled a multi-layered collaborative network that maximized the contributions of collaborators (i.e., Students, High School Teachers, Consultants, and Mentor) and enabled sustainability within the high school.
\end{abstract}

Keywords: Social Justice, Collaboration, High School, Diversity Training, Consulting 


\section{Introduction}

Social justice education aims to promote knowledge of social inequities and resistance to oppression, contributing to the development of civic engagement. There has been increasing attention within both the K-12 and higher-education settings to providing opportunities for students to have exposure to social justice topics (Thomann \& Suyemoto, 2017; Watts \& Flanagan, 2007; Zaff, Malanchuk, \& Eccles, 2008). However, despite increased interest and the existence of some examples (Carlisle, Jackson, \& George, 2006; Kraft, 2007; Portman \& Portman, 2002), designing, implementing, and sustaining social justice education initiatives may be challenging in $\mathrm{K}-12$ settings due to limited resources, training, and institutional support.

In this context, psychologists are often invited as outside instructors or consultants to offer social justice courses and to provide training. This practice offers psychologists opportunities to contribute to training beyond the academy and the profession, create impact within the community, and utilize their expertise and group facilitation skills. Providing training to K-12 students is essential, given research suggesting that early exposure to diversity topics, especially before entering higher education, could be beneficial for developing perspective-taking skills such as empathy, and understanding structural oppression (Thomann \& Suyemoto, 2017). While the practice of psychologists serving as consultants or instructors to teach high school courses may be a useful short-term measure, it is not necessarily sustainable, due to cost and time constraints within schools. Hence these opportunities require psychologists to consider the potential for a social justice educational model that continues to be sustainable at the high school, even after the psychologists must exit the system (Tauriac, Kim, Sariñana, Tawa, \& Kahn, 2013).

This paper describes a sustainable social justice education model that involves collaboration between university-based psychologists and high school educators. We draw our overall approach from previous research in implementation science (Halle, Metz, \& Martinez-Beck, 2013; McDonald, Eyster, Nightingale, \& Bovbjerg, 2013; Metz \& Bartley, 2013) and, this model is a multi-layered collaboration among multiple constituencies: high school students, high school teachers, consultants, and a mentor to the consultants. ${ }^{1}$ Collaboration, if developed correctly, creates a ripple effect with lasting impact; sustainability becomes possible, and opportunities emerge to move students and teachers from agents of change in the classroom to becoming agents of change in their communities without relying on outside consultants (e.g., Delp, Brown, \& Domenzain, 2005). This paper aims: 1) to provide a bestpractice model through which psychologists and educators collaboratively create a ripple effect in teaching about social justice, and 2) to present tools for other university-based and K-12 educators for a sustainable training model.

\section{Conceptualizing Social Justice}

Social justice has received more attention in recent years in the fields of education and psychology. However, conceptualizing it has posed challenges because of the breadth of its meaning and usage in different contexts (Shriberg \& Fenning, 2009). Social justice involves distributive, procedural, and relational justice, and should occur at multiple ecological levels. That is, resources should be distributed and processed equitably (Reason \& Davis, 2005; Shriberg \& Fenning, 2009); decisions are made in an equitable manner (Reason \& Davis, 2005); and individuals should be treated with respect and dignity

\footnotetext{
${ }^{1}$ From here on, we capitalize Students, High School Teachers, Consultants, and Mentor because they are identifiers for specific roles in this particular intervention. Capitalization makes it clear that we are referencing the role in relation to this intervention and not just the experience overall. For example, when we say "High School Teachers" we are not referring to all high school teachers, but to the role of High School Teacher in this intervention, and in relation to other roles.
} 
(Prilleltensky, 2012). Hence, social justice can be conceptualized as both the content and process of equity. These sub-dimensions of social justice are particularly relevant to consider when creating a social justice education curriculum, as they need to be reflected in the content and process of such courses.

\section{Social Justice Education in High Schools}

Both $\mathrm{K}-12$ and post-secondary educators have noted the need to engage in social justice education in the K-12 school systems, as early exposure may be particularly meaningful in developing social justice consciousness (Dover, 2009; Thomann \& Suyemoto, 2017; Watts \& Flanagan, 2007; Zaff, Malanchuk, \& Eccles, 2008). Broido (2000), in her phenomenological study with college students, identified six factors that contributed to development of social justice allies. They include: precollege attitudes; acquiring information - usually through structured college courses; meaning-making about social justice through discussions, self-reflection, and perspective taking; gaining confidence and empowerment; skills development; and other serendipitous opportunities, such as being recruited to participate in projects related to social justice. Precollege attitudes are particularly remarkable because students who had open and accepting attitudes toward diverse viewpoints toward others before college were poised to develop as social justice allies in college. While most participants in Broido's (2000) study reported having grown up in predominantly White contexts and did not yet develop theoretical or systemic understanding of oppression, they maintained an attitude that valued the importance of egalitarianism and equity for all people before entering college. Additional research has found that being introduced to social justice education prior to college could foster positive youth development, civic engagement, facilitate understanding, and promote action among allies and advocates (Suyemoto, Day, \& Schwartz, 2015; Thomann \& Suyemoto, 2017; Watts \& Flanagan, 2007; Zaff, Malanchuk, \& Eccles, 2008).

High school age could be a particularly significant moment for learning about social justice, as adolescents develop cognitive, emotional, and relational abilities. Abstract concepts examined in a social justice course may provide sociocognitive conflicts for adolescents and a context for promoting formaloperational thinking, as adolescents grapple with contradictions, alternatives, or multiple ideas (Bearison \& Dorval, 2002). Furthermore, adolescents' increasing abilities for emotional and social perspective taking, and thinking about self and others in multi-layered ways may promote critical examination of relational concepts. They may impact racial and ethnic identities, personal and group memberships, and inter-group relations (Charmaraman \& Grossman, 2010; Choudhury, Blakemore, \& Charman, 2006; French, Seidman, Allen, \& Aber, 2006; Phinney \& Alipuria, 1990; Thomann \& Suyemoto, 2017; van den Bos, van Dijik, Westernberg, Rombouts, \& Crone, 2011). Furthermore, social justice education may help students gain skills in problem-solving and self-agency (Welton, Harris, La Londe, \& Moyer, 2015).

\section{Turning Challenges into Opportunities: Collaboration between Psychologists and High School Educators}

While community-based social justice training programs for adolescents have had a positive impact for youth (e.g., Suyemoto, Day, \& Schwartz, 2015), implementing social justice education in the high school setting is a challenging endeavor. Educators and administrators often face the following obstacles: 1 ) few models of social justice education within secondary school settings; 2) challenges in implementing the courses, given the limited internal resources and training, particularly around psychological reactions and group processes in relation to teaching social justice courses; and 3) challenges to sustainability within the school, after departure of the Consultants (Dover, 2009; Picower, 2012; Roach \& Elliott, 2009). 
Models of social justice education. First, there are limited available models of social justice education in the secondary schools (Dover, 2009). If social justice education is included in the curricula, it is often embedded in different content areas, such as social studies, history, science, or language arts. Unlike counselor or teacher training in higher education, there have been relatively few examples of innovative curricula and pedagogical approaches that are specifically set-apart as social justice education, either working directly with students or through teacher training (Kraft, 2007; Portman \& Portman, 2002; Welton et al., 2015). Welton et al. (2015) described a case study of a semester-long social justice education elective course at a high school with 32 racially diverse students, ranging from the first year to juniors, who were recruited by the principal of the school. The course was taught by a teacher who identified as White and Jewish, and the research team observed classes and analyzed the course content and dynamics. They found that the social justice course had a positive impact in increasing awareness of multicultural group dynamics; connecting identity to power and privilege; gaining understanding about racial politics through participatory action research; mastering content on race, power, and privilege; and developing a common language for social justice.

Other than the few examples of high school social justice designated courses, most of the existing models of social justice education focus on working with younger children (Carlisle et al., 2006; Kraft, 2007; Portman \& Portman, 2002). For instance, through the examples of two small public schools in San Francisco (a K-8 school and a middle school), Kraft (2007) explained that social justice education focused on developing critical thinking, adopting culturally relevant teaching practices, and creating school-wide values around social justice. Portman and Portman (2002) illustrated that an 8-week school-based structured psychoeducational group (Empowering Students for Social Justice; ES ${ }^{2} J$ ) in an upper elementary and a middle school helped increase students' awareness and knowledge about social justice and advocacy skills.

Previous research studies also illustrate that an effective teacher training on social justice topics could be accomplished through the collaboration between university-based professionals and local schools (Blumer \& Tatum, 1999; Carlisle et al., 2006; Gill \& Chalmers, 2007). Carlisle, Jackson, and George (2006), through collaboration between an elementary school and a university, delineated core values for social justice education in schools, including inclusion and equity, high expectations, reciprocal community relationships, system-wide approaches, and direct social justice education and intervention. Gill and Chalmers (2007) described a two-year endeavor to develop and implement a teacher education program illustrating collaboration between the University of British Columbia's Faculty of Education and the Vancouver School Board. This program sought to address the cultural diversity of the specific schools and to train teachers to critically examine and challenge the status quo through addressing questions relating to identity, belonging, human rights, inclusion, diversity and social responsibility personally and in their classrooms and schools. The existent examples of social justice education suggest that positive collaboration between university-K-12 educators is possible; yet, there remains a gap in the literature regarding how psychologists could actively engage in this collaboration (e.g., managing group dynamics, working with challenging emotions).

Course implementation: resources and training. The second challenge for implementing social justice education in the secondary schools involves possible limitations of internal resources within high schools, particularly curricular and pedagogical preparation for teaching social justice content and process (Picower, 2012). A significant aspect of social justice education involves working with challenging emotions, such as guilt, anger, defensiveness, frustration, and sadness, and managing group dynamics in light of these emotions (Bishop, 2002; Goodman, 2011). Effectively working with effect through recognizing and managing these emotions by normalizing and exploring them is a crucial aspect 
of social justice education (Reason, Scales, \& Roosa Millar, 2005). In practice, many K-12 educators report that they are not well trained in the pedagogical approaches and management of challenging emotional- and group-processes involving social justice education (Philpott \& Dagenais, 2012). The collaboration described here between psychologists and high school educators. Psychologists were invited to be Consultants because of their expertise and experience working with individual- and groupprocesses and with knowledge of affect management. High school educators had familiarity with the students and school context. This collaboration may be a particularly good fit for implementing a social justice curriculum.

Sustainability. Finally, the third challenge for implementing social justice education is sustainability (Hurtado, Milem, Clayton-Pederson, \& Allen, 1998; Thompson, Hardee, \& Lane, 2011). While inviting consultants to teach the social justice courses in the secondary school's aids with implementation, this practice is frequently not sustainable, as the consultants must exit the system when funding is ceased. Capacity building within the school system, therefore, is critical (Roach \& Elliott, 2009). The second and third challenges listed here highlight a need for a model of social justice education between the K-12 educators and psychology Consultants, which is genuinely collaborative, layered, and capacity-building. One of the primary goals should be to have the educational model remain in the schools, by providing training opportunities and helping to strengthen the educators' roles within the school in delivering social justice education.

\section{Laying the Ground Work: Context at the Cambridge School of Weston (CSW)}

We describe teaching a social justice course at the Cambridge School of Weston, a private high school, as an example of a collaborative social justice education model. CSW is a progressive, coed, day and boarding, independent high school in Weston, Massachusetts. At the time of the consultation, the school had 325 students and 50 full-time faculty ( $26 \%$ faculty of color). The student body included both international students (10\%) and domestic students from the following racial groups: Asian (3\%), White (74\%), Black (5\%), and Latino/Latina (3\%). CSW's stated mission emphasized innovation, collaboration, community contributions, and civic engagement (http://www.csw.org/page/about/mission/) and the importance of diversity and multiculturalism (http://www.csw.org/page/about/board/diversity).

This work at the CSW could be described within the framework of implementation science. Implementation science has five stages: exploration, installation, initial implementation, full implementation, expansion and scale-up (Halle et al., 2013; McDonald et al., 2013; Metz \& Bartley, 2013). As described below, the CSW has started extensive work for the exploration stage, and the psychologists were invited to focus on installation and initial implementation of the social justice education at the school. Therefore, this manuscript focuses specifically on the collaborative work in the first three stages. The full implementation is currently on-going at the CSW, without the active involvement of the psychologists, as creating a sustainable model without the ongoing help of the outside consultants was the goal of the school.

\section{Exploration: Assessment of Community Goals}

The exploration stage focuses on assessing goodness of fit between the potential program to be offered and the needs of the community, including needed requirements for the program and potential barriers (Metz \& Bartley, 2012). With the recognition on the significance of teaching about diversity and social responsibility, the CSW conducted self-assessments related to campus climate and diversity-related, increased inter-racial group dialogues in light of racial tension, and invited outside speakers. CSW, then, involved its members in an internal discussion about offering a social justice course within the school. At that time, the CSW teachers' curricular and pedagogical expertise did not yet include social justice 
education. Hence, psychology Consultants (co-authors GSK, VDK, \& JT) from local universities were invited to meet with the CSW community to discuss the development of the course, structure, and goals, and to plan for co-teach the course. Three primary goals emerged to: 1) offer a social justice course with a focus on race, 2 ) empower students to become student leaders for civic engagement and develop student-focused initiatives to address racial and other tensions among the student body, and 3) embed the course into the CSW curriculum in a way that was sustainable.

\section{Installation: Social Justice Course Aims and Content Planning}

The second step of the implementation is the installation stage, in which resources are acquired, implementation is planned out, and staff and the organizations are prepared for the next stage (Metz \& Bartley, 2012). The psychology Consultants, through the discussions with the administrators at CSW, designed the "Alliance Building Leadership Exchange" (ABLE) course as a full-year course that meets bimonthly. CSW and the consultants agreed that the enrollment for the course should be open to students (sophomores to seniors) who submitted an essay about their interest in taking the course. Also, during this time, the CSW administration solicited volunteers for two teachers to serve as teacher liaisons who would work with the Consultants and informed the school community about the ABLE course.

This social justice education model had the following overall teaching aims: 1 ) creating opportunities to critically analyze issues related to equity, with a particular attention to race and racism; 2 ) helping students explore their privileges and marginalizations through self-reflection, focusing on identity development; 3) aiding students to develop empathy toward others and ally identities (Ayvazian, 1995) through peer collaborations and discussions, and 4) empowering students to take action and build leadership skills, by creating opportunities for individual and community action through the course content. The course was designed to pay particular attention to developmental processes in cognitive, interpersonal, and intrapersonal domains, and involved adjusting self-interests to collective interests (Edwards, 2007; Goodman, 2011; Waters, 2010).

The process of the social justice education model was also closely aligned with the philosophies of transformative education (Banks, 1996; Suyemoto, Tawa, Kim, Lambe, Nguyen, \& AhnAllen, 2009). Transformative education focuses on problematizing complex social variables, such as race, culture, class, and other areas of privileges and power; questioning of epistemology and social norms; including marginalized perspectives in course content; and personalizing knowledge. Transformative education explores interpersonal, and systemic manifestations of hierarchies of oppression and power and privilege (Suyemoto et al., 2009), and this exploration contributes to the recognition of personal responsibility.

The Consultants recognized that pedagogical approach to social justice education is different from traditional pedagogy. With the traditional pedagogy, instructors tend to focus on relaying the course content uni-directionally. Within social justice education context, however, there is an emphasis toward multi-directional learning and sharing of power in the classroom context, and attention is paid to the whole personhood of students, and equal attention to both the content and the process (Hoffman-Kipp, 2013). Social justice educators grapple with balancing the emotional and cognitive aspects of students' learning; and acknowledging and supporting the individual students' experience of oppression and privilege, while illustrating the systemic issues through power analysis. They attend to the group dynamics in the classroom, use experiential learning and reflection as teaching tools, and build skills. They value changes in awareness, personal growth, and change as outcomes of learning process (Adams, Bell, Goodman, \& Joshi , 2016; Bishop, 2002). Thus, the Consultants designed the course to be 
co-taught as a team, with topics, discussions, and assignments to capture both content learning and experiential activities. For an overview of the thematic course content and major assignments, please see Table 1 on the next page. 


\section{Table 1. Overview of the Personnel, Goals, and Activities}

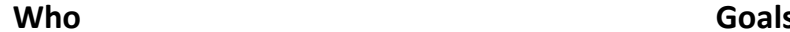

Goals

Activities

\section{Students:}

CSW juniors and seniors, who applied to take a course in social justice

\section{High School Teachers:}

Full-time permanent CSW faculty familiar with the school, students, administration. Highly interested in diversity and social justice. Plan to teach the course regularly in the future and train/consult/assist other CSW faculty who will eventually teach the course.
- Develop knowledge about oppression, privilege, inequity

- Develop skills to act for social justice and to become agents of change

- Develop content knowledge necessary to teach a course

- Develop an understanding of psychological processes of resistance, empathy, socialization for bias that play out in this kind of classroom

- Develop psychologically related skills and thinking to contribute to classroom management skills.
- Attend ABLE class

- Project/presentation/leader for others

- $\quad$ Provide feedback about the experience to consultants, CSW faculty, CSW Board

- Attend/observe an ABLE class

- Meet twice monthly with Consulting Instructors to discuss XX

- Regular email and conference call with Consulting Instructors to update the response to class, CSW environment, and community, holistic student experience or concerns, classspecific student experiences.

- Check-in with students as needed

- Meet regularly with the head of school

- Facilitate presentations about XX to the faculty of CSW

\section{Consultants}

Three university-based who were either a clinical psychologist or a psychologist-intraining. Trained together at a program emphasizing social justice and issues of race, culture, and diversity. Had experience to teach social justice related content at the University level. High School Teachers.
- Develop and implement a social justice curriculum for the year-long course

- Actively communicate and provide scaffolding to the High School Teachers for replication of the course

- $\quad$ Review the process of teaching practice among the Consulting Instructors and share every other week (21 sessions).
- Plan and design each class discussions, activities, and continue to modify in consultation with the Mentor and High School Teachers.

- Co-teach the 1-year course at CSW for 2 hours,

- Meet regularly (on a weekly to bi-weekly basis) among the Co-Instructors to plan the curriculum, discuss pedagogical approaches, and to engage in process discussions after each class.

- Meet twice/month with the High School Teachers to discuss the pedagogical process, challenges, and brainstorm next steps 
Mentor
Mentor to the consultants; University faculty

with research and teaching expertise in diversity, expertise in teaching for diversity, and curriculum development
- Mentor curriculum development process

- Mentor and supervise Consultants' experiences, review previous classes, discuss pedagogical strategies, develop/modify curriculum in response to class dynamics, and encourage attention to process dynamics at multiple levels: among the students; between Constant Instructors and students; among the Constant Instructors; and among the Constant Instructors, the TLs and CSW administrative community.

- Provide psychological lens for understanding intrapsychic and interpersonal progress and barriers to developing as allies and advocates

\section{School Administration}

CSW full-time administrators, including and led by the Head of the school, Dean of faculty, and Dean of students. Involved in the in discussions with CSW faculty and staff, and the CSW Diversity Committee.

- Build on the recommendation of the Diversity Committee to increase social justice focus in the school

- Actively support running a social justice course in preparation for developing a social justice curriculum
- Provide information to the CSW administration and the Board about the course

- Provide initial/sample curriculum and review/provide feedback on changes and tailoring

- Meet monthly with Cls for supervision

- Provide support as needed via email and phone
- Place the course in the academic schedule

- Create spaces for further communication and inform the school community about the course and its importance

- Communicated their support for short- and long-term offering of social justice curriculum 


\section{Initial Implementation of the Social Justice Education: Focusing on Collaboration}

The initial implementation process is a crucial stage in which "the new program model or initiative is put into practice," with a focus on continuous improvement and problem solving (Metz \& Bartley, 2012, p. 12). The psychology Consultants focused on collaboration as a critical element of the initial implementation and worked with the aim of exiting the system, as CSW wanted to work on fullimplementation stage independently without the Consultants' assistance. This model, as overviewed in Figure 1, requires collaborations across multiple members of the network, with a goal of creating a ripple effect across the entire school community. As noted by the bidirectional arrows, interactions occurred across and between multiple constituencies, and the relationships were bi-lateral. Table 2 provides specific details on the people and activities in the collaborative education model, and below, we describe the collaboration at each level.

Figure 1. A Collaborative Social Justice Education Model: Exploration to Full Implementation

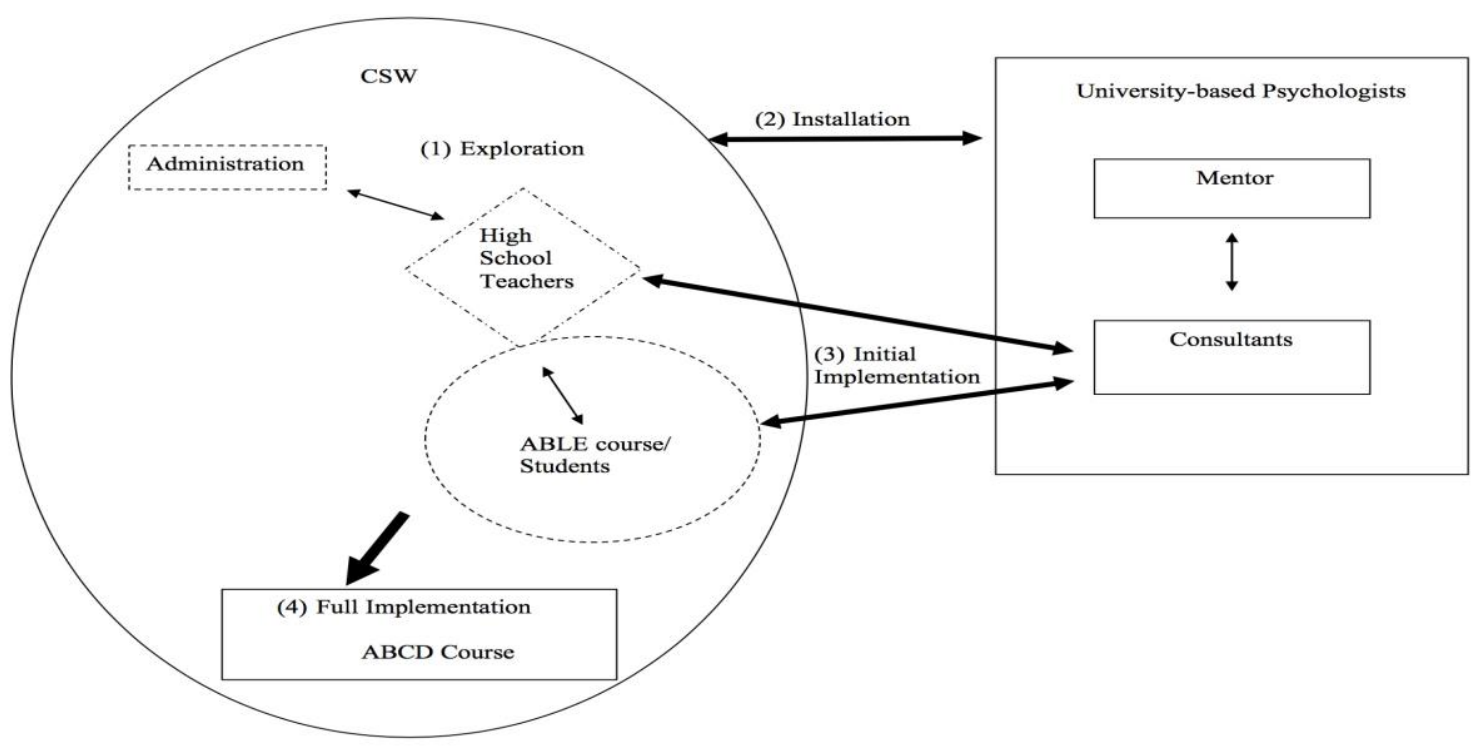


Table 2. Alliance Building Leadership Exchange (ABLE): Course Overview

\begin{tabular}{|c|c|}
\hline Content \& Discussion Themes* & Assignments \\
\hline Introductions & Journal \\
\hline $\begin{array}{l}\text { Exploring Differences overview - race, ethnicity, gender, } \\
\text { nationality, identity }\end{array}$ & Journal \\
\hline Political Dimensions \& Power - Stereotypes discussion & Implicit associations task \\
\hline Exploring Ethnicity & Journal \\
\hline Exploring Race and Racism & Journal \\
\hline $\begin{array}{l}\text { Exploring Intersecting Oppressions - Social Class \& Sexual } \\
\text { Orientation }\end{array}$ & $\begin{array}{l}\text { A day in someone else's flip-flops: Exercise in } \\
\text { empathy }\end{array}$ \\
\hline $\begin{array}{l}\text { Immersion project \& Group Empowerment Projects } \\
\text { Brainstorm }\end{array}$ & Journal \\
\hline Exploring Identities & Journal \\
\hline Exploring Power and privilege & $\begin{array}{l}\text { Immersion Project: visiting a racial or } \\
\text { cultural/religious community group in which one is } \\
\text { not a member of }\end{array}$ \\
\hline Being Allies & $\begin{array}{l}\text { Present/lead group empowerment } \\
\text { projects in the school community }\end{array}$ \\
\hline Reflections - Where do you go from here? & Journal \\
\hline
\end{tabular}

Collaboration among Consultants and Mentor. The first layer of the partnership is between the Consultants (co-authors GSK, VDK, JT), and the Mentor (co-author KLS), in designing and planning the course, having process reflections during the year, and trouble-shooting, as needed. Three Consultants, each of whom came from different racial and ethnic backgrounds, had experience in teaching and working with adolescents. However, they were early in their teaching career (two graduate students and one early career professional), and more importantly, they had never co-taught before. They sought regular consultations (through biweekly to monthly meetings) from their Mentor, who had experience with co-teaching collaborations of White teachers and teachers of color. This teaching consultation was significant in the collaboration model that created a ripple effect. The Mentor provided opportunities for exposure to alternate perspectives, insight and increased awareness, and opened new dialogues among the Consultants. The Consultants then shared process and content with the High School Teachers and incorporated this evolved content and experiential knowledge into their teaching, affecting Students, and in turn School Administrators who were actively involved in the school dynamics. Some of the specific foci of the collaboration included developing a course curriculum that built on the foundational course contents and yet remained flexible and paid attention to the relational process, and discussing process aspects of the in-class dynamics and the experiences of co-teaching. First, the Mentor helped to facilitate awareness of complex dynamics in the classroom by asking questions and providing an opportunity for the Consultants to reflect and purposefully use relational and emotional processes in the classroom. For example, the Consultants shared with the Mentor their observations that some students in the course struggled with their privilege and seemed to distance themselves from other students who were perceived as more privileged. Students explicitly and implicitly communicated that guilt was an "empty" or "useless" emotion. Through consultation with the Mentor, the Consultants 
named these dynamics and devised strategies to attend to and shift this dynamic in the classroom by engaging in class discussions on this topic.

Finally, the Mentor facilitated self-reflection and discussions about the interpersonal relationships among the Consultants, particularly around different areas of privilege. In this process, the Consultants realized that their awareness about different areas of privilege was mostly private; that is, they were mindful of them, but there was no prior explicit discussion about different privileges amongst the coteachers. The Mentor helped the Consultants to explicitly share how these privileged statuses interacted and affected the co-teaching. The Mentor encouraged the Consultants to use these reflections as teaching tools, to model cross-cultural alliances, and to promote change in the classroom. For example, they discussed how the Consultants could give or take away conversational space by making choices as simple as deciding who would be taking the lead on a topic or even whether or not to speak. Through sharing their observations, they learned that it might not be as effective for a person in marginalized social status to speak about that status (e.g., a racial minority immigrant Consultant leading a discussion on racism and immigration), because this may communicate that such issues only mattered to the marginalized. Instead, the Consultants agreed that those in the more privileged spaces would lead discussions on this area of privilege (e.g., White privilege, straight, CIS gender privilege), with the pedagogical goal of modeling that the pursuit of social justice is a matter that should be important for everyone.

Collaboration among the Consultants through co-teaching. The second layer of collaboration was focused among the three psychology Consultants, who actively chose to co-teach the ABLE course. Co-teaching offered opportunities to deepen the CSW students' understandings of the course content, and it provided opportunities to model ally processes within the teaching collaboration. The Consultants differed from each other in race, ethnicity, gender, immigration status, and sexual orientations. In addition to preparing for the specific schedules, activities, and tasks for each module, co-teaching of a social justice course needed an extensive effort put into process-oriented discussions and conversations about how the course materials related to the co-teachers. Quickly, the Consultants, with the guidance of the Mentor, realized the need for regular meetings to explore, discuss, and better understand their own and each other's lived experiences, mainly around shared or different areas of privilege. They recognized that the choices they were making (and modeling) in co-teaching were inevitably shaped by their experiences of intersecting power and privilege and how these dynamics were active within their relationships with each other. For example, JT explored what it meant to be the only man teaching with two women, and how identifying as a male teacher brought ascribed credibility as a teacher. At the same time, he also explored how being a multiracial person may place him in a place of less privilege, given the ways in which multiracial heritages have been marginalized in a U.S. racial context. GSK, the Asian American female Consultant, who was privileged in terms of educational status and sexual orientation, wondered about the ways in which her privileges might impact the co-teaching relationship. Simultaneously, she considered how her first-generation immigrant and minority status had challenged her educational experiences, in receiving racism and lacking support from certain professors. VDK, the White European American female Consultant explored how being White has privileged her, and how her sexuality has marginalized her simultaneously. Given these intersecting social statuses, the three Consultants engaged in continued and deliberate discussions that led to a relational power analysis among the co-teachers, in the context of the larger systems.

Second, through discussions and reflections, the Consultants examined the co-teaching dynamics and choices and brainstormed how to improve their co-teaching. At one point, Consultants were surprised to notice that they were each concerned about taking up too much space and potentially taking the voice 
from others, mainly because of areas in which they each had privilege. However, because of this concern, Consultants were hesitant to take the lead, because they each worried about others' reactions, hence missing opportunities in class. Through explicit discussions on this issue, the Consultants decided on mutual decision-making choices about who would take the lead, how to be empathically listening, and aid in various parts of the curriculum. Similarly, these deliberate co-teaching choices served as collaborative ways that demonstrated to our students how to be allies for each other. When appropriate, the Consultants also explicitly shared their thought process with the students in the course, to model their collaboration to students (e.g., why a straight-identified Consultant was starting a discussion on LGBTQ+ issues).

Collaboration between Consultants and High School Teachers. In addition to the collaboration among the Consultants, two High School Teachers served as the liaisons between the course and the CSW. The High School Teachers were experienced teachers at the school, who volunteered for the role because they were interested in learning about teaching a social justice course with the hopes of potentially teaching the class or modifying its format in the future. The High School Teachers served as a bridge between the instructors - who were still outsiders to the CSW setting-and the CSW administration, attending all class meetings, following up with students, and meeting regularly with the Consultants. The High School Teachers' presence created continuity for the Students between class sessions and helped to provide support and structure to Students outside of the classroom. Because the Consultants were not full-time faculty at the high school and had limited availability and presence on campus, the High School Teachers and Students could check in with each other as needed. In some ways, the Consultants were in the role of traditional consultants with the school (e.g., providing expert services and guidance). At the same time, the High School Teachers were also in the role of consultants to the Consultants, and they helped the Consultants to understand the culture of the school, and the school to apply the expertise of the Consultants.

At the organizational level, the presence of the High School Teachers was integral to the success of the social justice education endeavor. The High School Teachers regularly communicated with the administrators and faculty regarding the progress and prospects of the course. The High School Teachers helped the Consultants coordinate a presentation to the faculty and the members of the board that included a description of the course, their teaching goals, and students' descriptions of their learning process in the course. This presentation empowered the participating students and provided an opportunity for the faculty to understand the impact of the social justice education course and the importance of its future. Finally, the role of the High School Teachers was crucial in enabling future internal sustainability. During the course, the High School Teachers self-assessed and reflected on the possibility of teaching a social justice course in the future without the consultants. Hence, they benefited from being apprentice teachers in this curricular and pedagogical area as they observed the class in the process.

Collaboration with Students, and among Students. Finally, this collaborative social justice education model involves students as part of the collaboration network. Here, Students are viewed as collaborators who not only learn about social justice topics in a class setting but also inform each other in the class and peers outside of the class, about social justice topics, hence creating the ripple effects of the social justice content and process across the school community. Fostering Students as collaborators are challenging, as it may require an epistemological shift by the institution and the students themselves to understand students as valuable collaborators. Also, regardless of the specific role of student collaborators (e.g., as student representatives, workshop facilitators, TA's), placing such responsibility on students if they are not developmentally ready can be emotionally overwhelming and potentially 
disruptive to students' academic growth. These issues underscore the importance of a model of a collaborative network within the social justice education model. Without the High School Teachers' close and daily contact with Students, the Consultants would have been more concerned about the possible risks of utilizing students as collaborators.

While instructors should be thoughtful about students' roles in learning and teaching, when successful, Students can be important collaborators in social justice education and this experience can be empowering. Student collaborators have a unique understanding of and access to their peers' perspectives. They maintain an in-group status as students, and this positionality may enable them to build positive relationships and emerge with ideas for collaborative social justice action that speak to their peers.

The ABLE course assignments were designed intentionally to foster collaboration and leadership skills; for example, one assignment involved group outreach projects that were implemented within the CSW community. Students self-selected and designed year-long group projects, under the mentorship of the Consultants and the High School Teachers. Students pursued various projects, including creating a newsletter on intersections of identities; a workshop on internalized racism; a workshop on raising class awareness; a survey on religion/religious attitudes. Another group created a social mapping project that invited students to map out social and racial aspects of friendships on campus and then facilitated a lunchtime "mix-in" where students, who commonly sat together with racial and ethnic in-groups were assigned lunch seats that maximized the racial diversity at each table. The ABLE course fostered leadership in social justice issues, enabling students to become visible leaders within the community.

Students are also essential collaborators in their roles as representatives. The High School Teachers organized a presentation to the faculty related to decisions about sustaining the initiatives and invited the Consultants as well as student representatives. Students not only described the value of the course in the meeting but also took their initiative to "brief" the Consultants on the general climate among faculty regarding the prospect of the ABLE course becoming institutionalized. Feedback from many of the faculty present at the meeting emphasized that the students' voices were influential and contributed to garnering faculty support.

\section{Impact of Collaborative Social Justice Education: Full Implementation and Beyond}

Three specific impacts of the ABLE course emerged. First, the course had an impact on student learning and empowerment. As illustrated in the below excerpts from the final course evaluations, provided here with student permissions, students reflected on "how they see themselves and others, and the world." Here, a few sample quotations from students ranging in different grade levels are presented. Many students reported their desire to start conversations about issues related to social justice and wanting to pursue and create more opportunities in and out of the high school community:

This course pushed me...to start working with the school around social justice issues. Hopefully, next year I will be on the diversity committee, and I will be able to take part in more of the things we do school-wide about these topics. I feel like I am now equipped with the information I need to... [make] change happen in our school and other places. (female sophomore student's final reflection)

I have started to apply some of the concepts I have learned in ABLE toward some of my interests. For example, I added a racial (transit racism) aspect to my transportation project [for another class]. (male senior student's final reflection). 
I see my future role in continuing to start conversation. Being the seeds of change. Knowing that even when people say ignorant comments, it is my job not to get angry but instead to educate.... I see myself being an ally. I know that this is the type of work I want to do for the rest of my life, in friend groups, in peer groups, in whatever community I am a part of. I was given both emotional and academic support to know that it is possible to start conversations and groups wherever I go. I learned that others feel the same need to talk and share and think together about these issues. I think a lot about the power of a safe space. I am excited at the thought that all of us in ABLE can make these spaces elsewhere. (female junior student's final reflection)

I am so much more interested in these [social justice] issues and want to continue doing alliance work in college. I plan to attend an orientation program at school about racism/classism/sexism, etc. (female senior student's final reflection).

The second positive impact of the collaboration was a series of teacher workshops. Again, the High School Teachers had an essential role in discussing the impact of the course on the high school community. The year following the ABLE course, the teachers and administration designated specific times for diversity training in their professional development series and asked the Consultants to teach a short-term course to the teachers. Two of the three Consultants returned on three occasions and cotaught similar content to the teachers, creating further opportunities to explore issues related to diversity among teachers and administrators. The training modules for teachers captured similar themes to the student course, including exploring meanings of various social identities and being an ally to others.

The third impact of the collaboration involves the start of the full implementation and the systems-level policy changes. Two years following the initial implementation of the ABLE course, the two High School Teachers further developed and modified the ABLE course and integrated the content into the curriculum in English and History. Since this time, CSW offers a similar course to ABLE, now called "Alliance Building across Cultural Divisions (ABCD)." CSW has also created a Social Justice graduation requirement, which could be met by taking at least 12 courses that reflect on different perspectives on the multicultural world, being the first independent school to institute such a requirement (https://www.csw.org/page/Academics/Social-Justice-Requirement).

The initial implementation of the social justice education model has successfully led to the full implementation of the course. The Consultants have exited the system, but through collaboration, the High School Teachers developed skills in teaching social justice courses and could move the teaching "inhouse" and decreased outside consultation needs and the financial impact. Consultants may become Mentors in the next offering of the course; in-house Consultants may consider having Students who have completed the course as Teaching Assistants (TAs) in the following year, who will be role models for current students, working as liaisons and consultants between the faculty and the student body. Therefore, the model does not depend on few individuals who are the sole experts, but that it creates a ripple effect in disseminating knowledge and process required for teaching and learning about social justice education.

\section{Thinking about Big Pictures: Limitations and Implications}

While this multi-layered collaborative consultation model for social justice education has been successful, its success has a few contexts in which it may pose challenges in its generalizability to other settings. One limitation to generalizability is that this model was utilized at a school, which had been 
preparing and self-assessing for some years, with an increased number of people in the community hoping for a social justice curriculum. The readiness of the school, and especially the support of administration and faculty were extremely crucial to starting a social justice education course. Because this work may take a few years to become a regular part of the curricula, sustained commitment and support from different constituencies within the school, and especially those of the administration, is vital. A thoughtful assessment of institutional readiness and commitment may be needed in other contexts in beginning collaboration such as the model presented in this paper.

Another important factor to note is that as an independent private school, CSW was both relatively well resourced and had designated resources toward social justice education because of its mission. Also, the current political climate and polarizing political attitudes could serve as a barrier to offering social justice courses such as this one. Some may perceive exploration of social justice issues as a topic that should not belong in the high school education.

Finally, in the challenging economic climate, funding may be a limitation for institutions seeking to begin a collaborative consultation or to incorporate courses with team-teaching and collaborative participation at multiple levels. One way to enable collaborative social justice education might be collaboration in research and teaching. Consultants may be willing to teach at reduced fees if they may simultaneously conduct educational research to further their academic careers. Such research could also be valuable to the school for gathering data on the needs of their students and impacts of innovative programs, and for increasing funding opportunities through grants based on empirical data. Another potential model of collaboration for universities and K-12 schools may involve active and systemic collaboration involving participation and supervision of graduate students seeking teaching careers. As adopted in our experience at CSW, where Consultants split the pay of a single course, it may be possible to create a training model in which graduate students co-teach courses at reduced fees for each in return for valuable supervised teaching opportunities such as those described here. A further consideration for active collaboration between psychologists and K-12 school systems would be crucial for psychologists to contribute more actively to the communities outside of the higher education or consulting rooms while utilizing the unique skill sets and training as psychologists.

\section{Author Contact Information}

Grace S. Kim, Counseling Psychology \& Applied Human Development, Wheelock College of Education and Human Development at Boston University. Vali D. Kahn is now in independent practice in Cambridge, MA. John Tawa, Psychology and Education Department at Mount Holyoke College. Karen L. Suyemoto, Psychology and Asian American Studies at the University of Massachusetts Boston.

Correspondence concerning this article should be addressed to: Grace S. Kim, Counseling Psychology \& Applied Human Development, Wheelock College of Education and Human Development, Boston University, 200 Riverway, Boston, MA 02215. Email: gkim15@bu.edu.

\section{Acknowledgment}

We thank the students, teachers, and administrators at Cambridge School of Weston for their vision and collaboration toward social justice education. 


\section{References}

Adams, M., Bell, L. A., Goodman, D. J., \& Joshi, K. Y. (Eds.). (2016). Teaching for diversity and social justice. ( $3^{\text {rd }}$ Edition). New York: Routledge.

Ayvazian, A. (1995). Interrupting the cycle of oppression: The role of allies as agents of change. Fellowship, January/February, 7-10.

Banks, J. A. (1996). Transformative knowledge, curriculum reform, and action. In J. A. Banks (Ed.)., Multicultural education, transformative knowledge, \& action: Historical and contemporary perspectives, (pp. 3-29). New York, NY: Teachers College Press.

Bearison, D. J., \& Dorval, B. (2002). Collaborative cognition: Children negotiating ways of knowing (Advances in discourse processes). Westport, CT: Ablex Publishing. doi:10.5860/choice.39-6107

Bishop, A. (2002). Becoming an ally: Breaking the cycle of oppression in people. (2 ${ }^{\text {nd }}$ ed.). New York, NY: Zed Books.

Blumer, I., \& Tatum, B. D. (1999). Creating a community of allies: How one school system attempted to create an anti-racist environment. International Journal of Leadership in Education, 2, 255-267. doi:10.1080/136031299293057

Broido, E. M. (2000). The development of social justice allies during college: A phenomenological investigation. Journal of College Student Development, 41, 3-18.

Carlisle, L. R., Jackson, B. W., \& George, A. (2006). Principles of social justice education: The social justice education in schools project. Equity and Excellence in Education, 39, 55-64. doi:10.1080/10665680500478809

Charmaraman, L., \& Grossman, J. M. (2010). Importance of race and ethnicity: An exploration of Asian, Black, Latino, and multiracial adolescent identity. Cultural Diversity and Ethnic Minority Psychology, 16, 144-151. doi:10.1037/a0018668

Choudhury, S., Blakemore, S.-J., \& Charman, T. (2006). Social cognitive development during adolescence. Social Cognitive and Affective Neuroscience, 1, 165-174. doi:10.1093/scan/nsl024

Delp, L., Brown, M., \& Domenzain, A. (2005). Fostering youth leadership to address workplace and community environmental health issues: A university-school-community partnership. Health Promotion Practice, 6, 270-285. doi:10.1177/1524839904266515

Dover, A. G. (2009). Teaching for social justice and K-12 student outcomes: A conceptual framework and research review. Equity \& Excellence in Education, 42, 506-524. doi:10.1080/10665680903196339

Edwards, K. E. (2007). Aspiring social justice ally identity development: A conceptual model. NASPA Journal, 43, 39-60. doi:10.2202/1949-6605.1722 
French, S. E., Seidman, E., Allen, L., \& Aber, J. L. (2006). The development of ethnic identity during adolescence. Developmental Psychology, 42, 1-10. doi:10.1037/0012-1649.42.1.1

Gill, H., \& Chalmers, G. (2007). Documenting diversity: An early portrait of a collaborative teacher education initiative. International Journal of Inclusive Education, 11, 551-570. doi:10.1080/13603110600600986

Goodman, D. J. (2011). Promoting diversity and social justice: Educating people from privileged groups. New York, NY: Routledge. doi:10.4324/9780203829738

Halle, T., Metz, A., \& Martinez-Beck, I. (2013). (Eds.). Applying implementation science in early childhood programs and systems. Baltimore, MD: Paul H. Brooks Publishing Co.

Hoffman-Kipp, P. (2013). Model activity systems: Dialogic teacher learning for social justice teaching. Teacher Education Quarterly, 30(2), 27-39.

Hurtado, S., Milem, J.F., Clayton-Pedersen, A.R., \& Allen, W.R. (1998). Enhancing campus climates for racial/ethnic diversity: Educational policy and practice. The Review of Higher Education, 21, 279-302. doi:10.1353/rhe.1998.0003

Kraft, M. (2007). Toward a school-wide model of teaching for social justice: An examination of the best practices of two small public schools. Equity and Excellence in Education, 40, 77-86. doi:10.1080/10665680601076601

McDonald, E., Eyster, L., Nightingale, D., Bovbjerg, R. (2013). Literature review: Analyzing implementation and systems change - Implications for evaluating HPOG, OPRE Report \#2013-25. Washington, DC: Office of Planning, Research, and Evaluation, Administration for Children and Families. U.S. Department of Health and Human Services.

Metz, A., \& Bartley, L. (2012). Active implementation frameworks for program success: How to use implementation science to improve outcomes for children. Zero to Three, 34, 11-18.

Philpott, R., \& Dagenais, D. (2012). Grappling with social justice: Exploring new teachers' practice and experiences. Education, Citizenship, and Social Justice, 7, 85-99. doi:10.1177/1746197911432590

Pettigrew, T. F., \& Tropp, L. R. (2008). How does intergroup contact reduce prejudice? Metaanalytic tests of three mediators. European Journal of Social Psychology, 38, 922-934. doi:10.1002/ejsp.504

Phinney, J. S., \& Alipuria, L. (1990). Ethnic identity in older adolescents from four ethnic groups. Journal of Adolescence, 13, 171-183. doi:10.1016/0140-1971(90)90006-s

Picower, B. (2012). Practice what you teach: Social justice education in the classroom and the streets. $\left(1^{\text {st }}\right.$ ed). New York, NY: Routledge. doi:10.4324/9780203118252

Prilleltensky, I. (2012). Wellness as fairness. American Journal of Community Psychology 49, 121. doi:10.1007/s10464-01109448-8 
Portman, T. A. A., \& Portman, G. L. (2002). Empowering students for social justice (ES[squared]J): A structured group approach. Journal for Specialists in Group Work, 27, 16-31. doi:10.1177/0193392202027001003

Reason, R. D. \& Davis, T. L. (2005). Antecedents, precursors, and concurrent concepts in the development of social justice attitudes and actions. In R. D. Reason, E. M. Broido, T. L. Davis, \& N. J. Evans. (Eds). Developing Social Justice Allies, New Directions for Student Services, 110, 5-15. doi:10.1002/ss.161

Reason, R. D., Scales, T. C., \& Roosa Millar, E. A. (2005). Encouraging the development of racial justice allies. In R. D. Reason, E. M. Broido, T. L. Davis, \& N. J. Evans. (Eds). Developing Social Justice Allies, New Directions for Student Services, 110, 55-66. doi:10.1002/ss.165

Roach, A. T., \& Elliott, S. N. (2009). Consultation to support inclusive accountability and standards-based reform: Facilitating access, equity, and empowerment. Journal of Educational and Psychological Consultation, 19, 61-81. doi:10.1080/10474410802463320

Shriberg, D., \& Fenning, P. A. (2009). School consultants as agents of social justice: Implications for practice: Introduction to the special issue. Journal of Educational and Psychological Consultation, 19, 1-7. doi:10.1080/10474410802462751

Suyemoto, K. L., Day, S. C., \& Schwartz, S. (2015). Exploring effects of social justice youth programming on racial and ethnic identities and activism for Asian American youth. Asian American Journal of Psychology, 6, 125-135. doi:10.1037/a0037789

Suyemoto, K. L., Tawa, J., Kim, G. S., Day, S. C., Lambe, S. A., Nguyen, P. T., \& AhnAllen, J. M. (2009). Integrating disciplines for transformative education and health services: Strategies and effects. In L. Zhan (Ed.), Asian American voices: Engaging, empowering, and enabling (pp. 209-228). New York: NLN Press.

Tauriac, J. J., Kim, G. S., Sariñana, S. L., Tawa, J., Kahn, V. D. (2013). Utilizing affinity groups to enhance intergroup dialogue workshops for racially and ethnically diverse students. The Journal for Specialists in Group Work, 38, 241-260. doi:10.1080/01933922.2013.800176

Thomann, C. R. B. \& Suyemoto, K. L. (2017). Developing an anti-racist stance: How white youth understand structural racism. The Journal of Early Adolescence. February 12, 2017, doi:10.1177/0272431617692443

Thompson, C., Hardee, S., \& Lane, J. C. (2011). Engaging student diversity through a social justice learning community, Journal of Diversity in Higher Education, 4, 106 - 119.

van den Bos, W., van Dijik, E., Westernberg, M., Rombouts, S. A. R. B., \& Crone, E. A. (2011). Changing brains, changing perspectives: The neurocognitive development of reciprocity. Psychological Science, 22, 60-70. doi:10.1037/a0022726

Waters, R. (2010). Understanding allyhood as a developmental process. About Campus, November/December, 2-8. doi:10.1002/abc.20035 
Welton, A. D., Harris, T. O., La Londe, P. G., \& Moyer, R. T. (2015). Social justice education in a diverse classroom: Examining high school discussions about race, power, and privilege. Equity \& Excellence in Education, 48, 549-570. doi:10.1080/10665684.2015.1083839

Watts, R. J., \& Flanagan, C. (2007). Pushing the envelope on youth civic engagement: A developmental and liberation psychology perspective. Journal of Community Psychology, 35, 779-792. doi:10.1002/jcop.20178

Zaff, J. F., Malanchuk, O., \& Eccles, J. S. (2008). Predicting positive citizenship from adolescence to young adulthood: The effects of a civic context. Applied Developmental Science, 12, 38-53. doi:10.1080/10888690801910567 